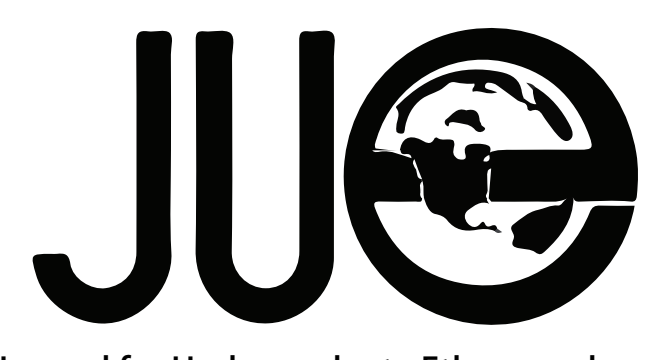

The Journal for Undergraduate Ethnography

Volume 6 | Issue 2

ISSN 2369-8721

\title{
"Vem Pra Rua": Music, Race and Social Media in the Brazilian World Cup Protests of 2013
}

\author{
G. Maris Jones \\ Brown University, gillian_jones@alumni.brown.edu
}

\section{ABSTRACT}

$\mathrm{n}$ Brazil, music and citizenship have long gone hand in hand. Based upon fieldwork in Salvador, Bahia, this article seeks to answer the following question: What is the relationship between Afro-Brazilian percussion, black identity, and youth activism? To address this question, I argue that black-identified music is a unifying tool used by citizens to assert their claims to rights and that in Brazil the demands for said rights cannot be separated from racial and socio-economic dynamics. To support my argument, I present a case study centered on the use of Afro-Brazilian percussion in the Confederations Cup protests of 2013 to illustrate how music is being used in the fight for rights today. I outline the circumstances that gave rise to nationwide demonstrations and provide thick description of two instances of protest I witnessed in Salvador. Next, I dissect a widely dispersed protest song from 2013 within the context of Brazil's history of protest music. Lastly, I look at the importance of social media in the breadth and scope of this social movement and government response. 


\section{Introduction}

In Salvador, Bahia, Brazil, black culture and music have been at the center of local resistance efforts against injustice for decades. From the 1970s into the 1980s, re-Africanization-the new affirmation of black identity_began to emerge in Salvador. During this period, black traditions and institutions were reinterpreted, and transatlantic emblems of blackness were adopted, including the Black Power salute and the pan-African colors green, yellow, red, and black. There was also a rise of new models of collective organizing based on identity politics, such as the blocos afro (Afro-Brazilian drum corps) that use rhythm as a method of resistance. Black transnationalism played an important role in the growth of re-Africanization, especially in the context of the African-American Civil Rights Movement and the development of Jamaican reggae. Significantly, Olodum and Ilê Aiyê, the most famous blocos afro, were inspired by the Black Consciousness Movement and employed symbols from across the African diaspora. By drawing on these visual aesthetics and musical styles, blocos afro were able to align themselves with a larger, transnational affirmation of blackness. These groups effectively changed the previously white, European face and sound of carnival in Salvador forever.

Historically, race relations in Brazil have been portrayed in opposition to the black-white dichotomy of the United States. Brazil has been praised for its supposed racial integration and abundance of racial categories. Nevertheless, structural racism along with socio-economic discrimination has played and continues to play as significant a role in Brazil as it does in the United States. This is unsurprising given that according to the 2010 census, 51 percent of the Brazilian population identifies as preto (black/darkskinned) or pardo (brown) (IBGE 2011). The majority of the black population lives in the North and Northeast regions. In Salvador, a city known as "A Roma Negra" (The Black Rome), the numbers of Afro-descendants are even greater than the national average: $76.3 \%$ of the population self-identified as preto or pardo (IBGE 2011).

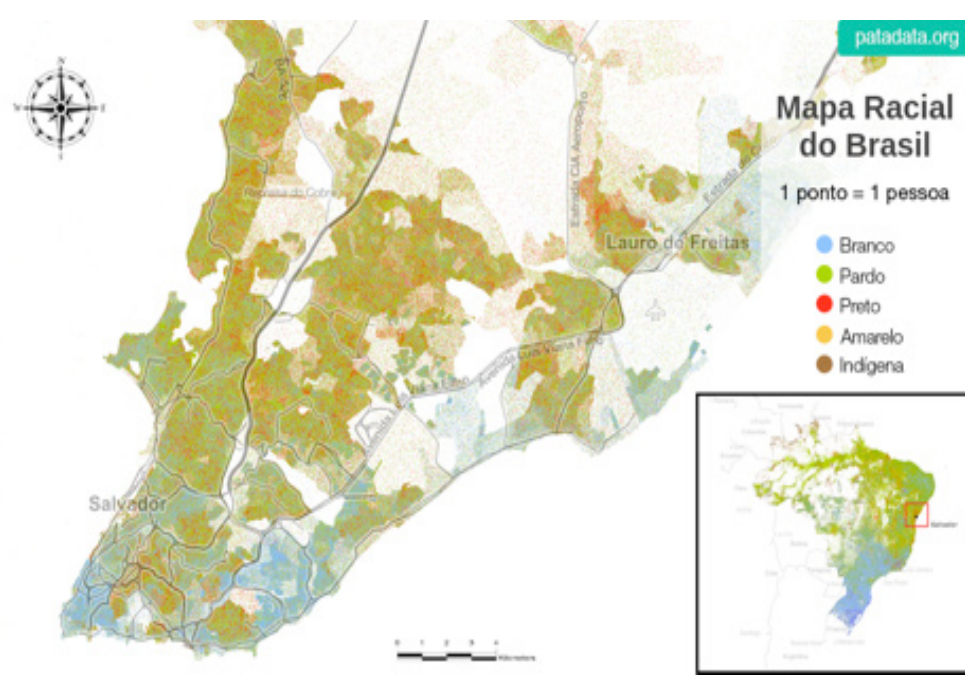

Figure 1. Racial dot map comparing Brazil as a whole to a section of the reconcavo baiano (coastal inlet of All Saint's Bay) in the northeast, focusing on the city of Salvador. Each dot represents one person in one of the five racial categories of the census: branco (white), pardo (brown), preto (black/dark-skinned), amarelo (yellow/Asian), or indigena (indigenous). Coincidentally, the blue areas indicating a significant concentration of white Brazilians on both maps are also the wealthier regions. Map based on 2010 census data from IBGE; processed and mapped by Rafael Viana, João Paulo Apolinário, and Tiago Gama. Individual maps edited into single image by author.

The goal of this a rticle is to examine the use of music as black-identified cultural production within the framework of youth activism in Brazil. In particular, I explore the adoption of Afro-Brazilian percussion as a means of celebration and resistance in protests in Salvador. Through ethnographic fieldwork and textual analysis I sought to answer the following questions: What is the relationship between Afro-Brazilian percussion, black identity, and youth activism? How have groups of young people employed music and social media, in an effort to lay further claim to their rights? I posit that black-identified music is a unifying tool used by Bahian citizens to assert their claims to rights, while simultaneously affirming that the demands for said rights through nationwide protests cannot be separated from the racial and socio-economic dynamics of Brazil. To support this argument, I first outline the methodology for my ethnographic research; I then explore, through a literature review, the historical intersection of cultural activism and Afro-Brazilian identity, and the implications of employing 
finally, I present a case study on the use of music and social media in the protests I witnessed during my fieldwork in Salvador.

\section{Methodology}

To address my research questions, I spent a total of ten months in Brazil immersing myself in various aspects of Brazilian society. During the summers of 2013 and 2014 I conducted primary and secondary research in Salvador, on which this article draws. Importantly, my identity as a black woman from New Orleans with Afro-Caribbean roots and my near-native fluency in Portuguese determined the spaces I was able to access and the way people treated me. In many ways, I was invisible-passing for Afro-Brazilian-until someone discovered my country of origin. After three years of Portuguese language study, I was able to speak the language fluently. Thus, my Brazilian accent often put me in the position of being praised as a highly skilled foreigner. However, when paired together, my blackness and my Portuguese fluency erroneously marked me as belonging to the marginalized group. Being an African-American passing for Afro-Brazilian encompassed positive and negative experiences, intensified the feeling of being an "outsider within" (Collins 1986), and created within me a sense of "double-consciousness" (Du Bois 1903).

In instances when these interactions were more positive, my near-native fluency in Portuguese was venerated and my Americanness was usually explained away with the fact that I possessed uma alma brasileira (a Brazilian soul). When combined with my black identity, I found that my informants were more than willing to share their stories with me during interviews and wanted to know about parallels in my life. Moreover, I was never harassed in the way that many of my white American friends were. Subsequently, I was able to venture into more "dangerous" (read: impoverished and non-white) territory without fear.
However, I also experienced racism and discrimination in ways that my white American colleagues did not. For instance, when waiting to meet a friend at a hotel in Rio de Janeiro, my blackness identified me as a non-belonging other. Despite being well dressed, I knew I was being watched; black women in high-end establishments are often perceived as prostitutes. Several staff members came to ask if they could help me; I politely responded in Portuguese that I was waiting for a friend. Though they continued to watch me uneasily, I was not asked to leave. When my friend arrived and we began speaking in English, I could feel the tension in the room ease. The kind of subtle racism I experienced in Brazil gave me a glimpse into the everyday experiences of Afro-Brazilians. Yet, unlike me, they did not have the option to pull the "foreign black card." In the larger scheme of blackness in Brazil, my American identity gave me a higher status and allowed me to use my othered blackness to escape from situations like the one described above. This knowledge made me uncomfortable.

In June of 2013, I arrived in Salvador and spent my first month becoming acquainted with the city and engaging in participant-observation. Having studied Afro-Brazilian percussion since 2009, I enrolled in supplementary lessons with drumming master Bira in the historic area of Pelourinho. With him, I learned well-known Bahian rhythms including samba-reggae, funk, samba-merengue, and rhythms associated with Candomblé (Afro-syncretic religion). During our sessions, I conducted several formal and informal interviews with Bira and community members he introduced me to. Over the course of my two summers, his shop became my home base-a safe place to which I could always return. My connection to Bira and his family opened many doors in the Pelourinho neighborhood, and I was able to observe practices and performances of local blocos afro, including Olodum. 


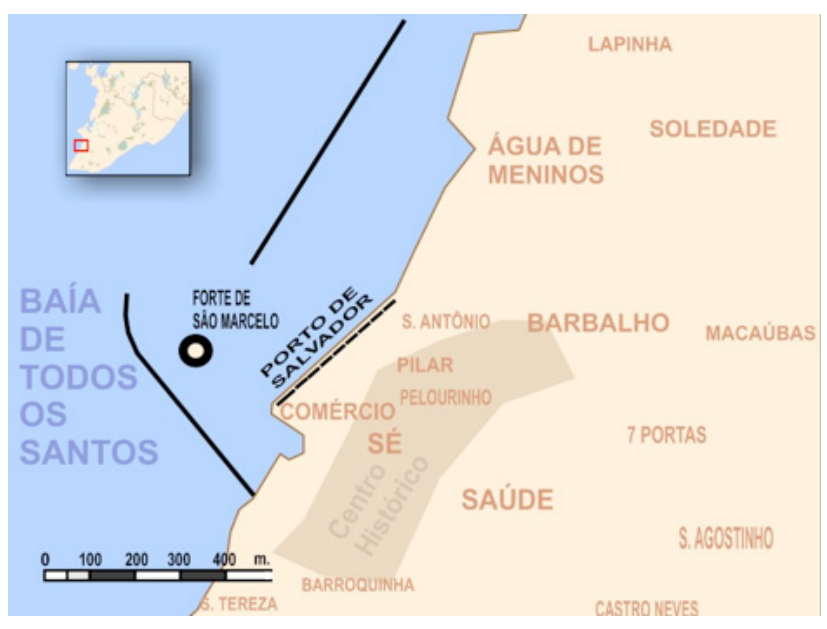

Figure 2. Map showing neighborhoods in the centro histórico (historic center) of Salvador and the location of Pelourinho in proximity to All Saint's Bay. Image created by André Koehne (2007)

My first month in Salvador coincided with the Fédération Internationale de Football Association (FIFA) Confederations Cup, in which Brazil competed as the following summer's World Cup host. I watched all of the soccer matches on television with the masses gathered outside Bira's shop. There, I photographed the throngs of people that passed by in the street and crowded around to buy cans of beer while they watched the game through the shop's window. Watching television was necessary for my consideration of the atmosphere created by the Copa (cup). It drew my attention to the discrepancy between the number of black and brown faces in the stadium audiences on television compared to those I saw in the street. Nevertheless, a sea of yellow with crests of green filled both the stands and the streets, and I joined in the collective swing. For each of Brazil's games, the air vibrated with the rhythms of Olodum as they performed in Pelourinho. I observed how people engaged with each other in public spaces and how they interacted with the ever-present military police.

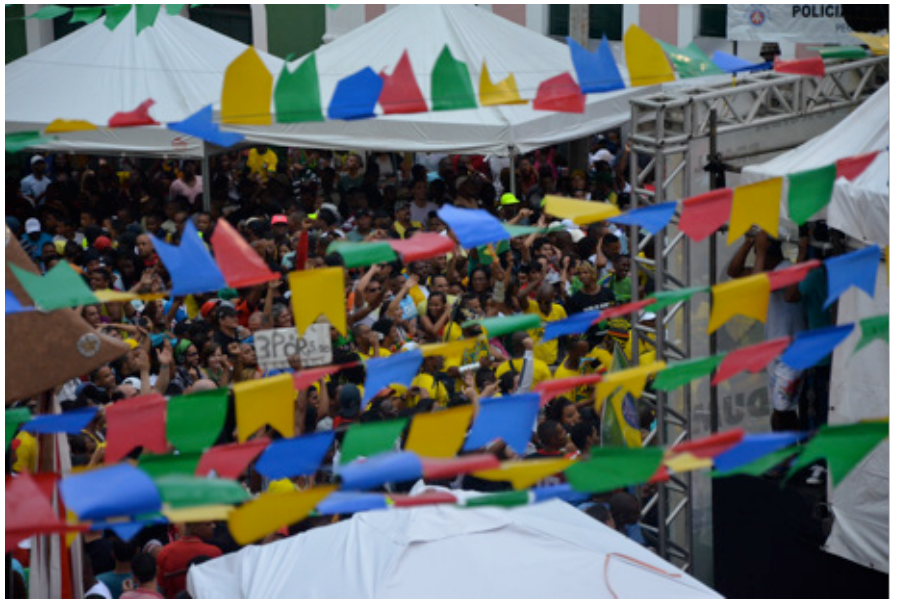

Figure 3. Image depicting a crowd simultaneously watching an Olodum performance and a soccer match during the Confederations Cup. A station for the policia militar (military police) can be seen in the top righthand corner. The flags waving in the foreground decorate the historic city center annually during the festas juninas (June festivals) celebrating St. John the Baptist, St. Anthony, and St. Peter. Photograph by author.

In Brazil, celebration and resistance often seem to go hand in hand, and the protests of June 2013 significantly shaped the landscape in which I conducted my research. The FIFA Confederations Cup also coincided with widespread bus strikes. Nationwide, there was an attempt to increase public transportation fares, and young Brazilians took to the streets in protest in all major cities. What began as widespread demonstrations against the price hike grew to include the people's frustrations with the policies of the ruling class, and inadequacies in the public and social services guaranteed by law. Moreover, there was frustration over the misappropriation of public funds in the building of new stadiums for the FIFA World Cup, including Salvador's Itaipava Arena Fonte Nova ("New Fountain Arena”, sponsored by Itaipava beer). 
During these demonstrations, the military police were omnipresent and often violent. Most protests were peaceful until the military police intervened and caused riots, resulting in civilian injuries and deaths. News coverage on Rede Globo (globe network), Brazil's television monopoly, looped footage of officers throwing teargas bombs into crowds, beating civilians with nightsticks, and indiscriminately shooting people with rubber bullets. Izabel, my host aunt, discouraged me from participating in the protests, saying that it was not my fight. "You look just like any other nigger" in the street, she warned-my status as a foreigner would not protect me as it did those of European descent. Though I tried to avoid direct engagement, the bus strikes often left me stranded in the city center where the majority of the protests occurred. Moving through the crowds, I documented what I saw through photography. At each of the protests that I observed in Salvador, there were always musicians integrating percussion into the demonstrations and driving the different chants.

\section{Literature Review: Afro-Brazilian Cultural Production and Community-based Mobilization}

To supplement my fieldwork, I undertook a literature review to gain a better understanding of the relationship between Afro-Brazilian percussion, black identity, and youth activism based on the previous works of experts.

Michael Hanchard's book Orpheus and Power (1998) argues that while culture is a force that has the ability to unite people, "culturalist" (as opposed to cultural) practices have also impeded "certain types of counter-hegemonic political activities because of their reproduction of culturalist tendencies found in the ideologies of racial democracy and in Brazilian society more generally" (1998, 21). Hanchard's analysis is not intended to denounce culture as valueless in political struggles, but rather to point out that cultural practice and identity formation alone cannot, and will not, make institutional change when fetishized and considered as ends in themselves. It is easy for these culture-focused efforts to remain disconnected from other kinds of more substantive remediation.

In Hanchard's analysis, blocos afro are an example of relatively successful "race-first" entities that have been able to bridge the gap between the cultural and the political, and to utilize racial identity as a principle to organize collective action. In an earlier article, Hanchard (1994) argues that blackness is perceived to be the antithesis of modernity, which is a major component of citizenship in the West. As a result, Afro-Brazilians have been consistently excluded from full citizenship in Brazil simply because of the color of their skin and socio-cultural practices associated with it. Despite this, members of blocos afro celebrate their blackness. Hanchard exalts the fact that the blocos afro operate outside the canon of national symbols that constrain their counterparts (the samba schools of Rio de Janeiro), and utilize Afro-Brazilian and pan-African identities and racial discrimination as principal themes.

Going beyond Hanchard's argument that cultural expression alone is not enough to incite change, George Yúdice (2003) looks at how culture is invoked as a problem-solving mechanism in multicultural societies. Importantly, he addresses the issue of government cooption of culture-as-resource. Both preservation and gender- and race-sensitive investment in culture are seen as ways to strengthen civil society, which ultimately serves as the ideal site for political and economic development.

Most relevant to this article is Yúdice's engagement with the idea of cultural agency, and his critique of the usefulness and efficacy of "cultural" NGOs and community activist organizations in Brazil. Yúdice reasons that cultural activism is a process of multilevel negotiation among various entities and that social strife can be transformed "into a resource that 'NGOized' cultural groups can mobilize to seek empowerment" $(2003,6)$. Yúdice argues that though different forms of black 
diasporic music are used to open space for activism and contest power structures, culture also functions as a mechanism to maintain marginalized groups' oppression through social management. Thus, culture becomes a battleground where managerial regimes can divert the political efforts of cultural and identity-based groups. In Brazil, this is further bolstered by brasilidade (Brazilian-ness), a racial discourse of inclusion that has long been a tactic for suppressing racial and cultural-affirmation-based movements. If culture is communal then there is no basis for reclamation of rights and resources.

The useful anthology Brazilian Popular Music and Citizenship (Avelar and Dunn 2011) moves beyond the broadness of culture as an apparatus in social mobilization to focus on popular music as a tool used by disenfranchised groups to assert claims to citizenship. For the authors, music is both an agent and an image of citizenship, and in the Brazilian context it has played a role in challenging the foreclosure of citizenship for certain subaltern groups. Definitions of citizenship, including who constitutes a citizen, and what rights are associated with an individual's status as a citizen within a democracy, have been highly variable across cultures, societies, and nations. This book also challenges Hanchard's assertion that culture has not promoted institutional change and offers a critical look into selected instances where the relationship between musical practices and the production of citizenship in the process of political and social transformations can be observed. Particularly relevant is Fredrick Moehn's contribution (2011), which explores how discourse about music and musical practices narrates the "audiotopia" (Kun 2005, 14)-the metaphorical space that music helps us imagine and has the possibility to be a safe haven-between factions of a stratified society. Moehn suggests that the ambiguous musical space where culture meets class, history, violence, and the state can be a refuge from both or either of the two Brazils-the privileged and the marginalized. He also suggests that that space of audiotopia can be a place where people can mobilize, as in the example of artists who use music as a way to critique social exclusion and promote citizens' rights. In the following case study, I will explore the creation of an audiotopia during the Confederations Cup protests of 2013.

\section{The Audiotopia of the Confederations Cup}

When I arrived in Salvador in the summer of 2013, I met Brazil in a state of unrest. As mentioned above, there was a series of protests in all of the country's major cities sparked by a twenty-cent increase in the cost of transportation. Known as the "manifestações dos 20 centavos" (twenty-cent demonstrations) or the "jornadas de junho" (journeys/days of June), the protests coincided with the FIFA Confederations Cup. Here, I focus on the role of music in marches and demonstrations in Salvador. I first outline the circumstances that gave rise to nationwide protests. Then, I provide thick description of the two instances of protest that I witnessed in Salvador, each of which incorporated elements of Afro-Brazilian percussion. Next, I dissect the song "Vem Pra Rua," the anthem of protestors in 2013, within the context of Brazil's history of protest music. Finally, I look at the importance of social media in the breadth and scope of this social movement and government response.

Never underestimate the power of twenty cents. In 2013, 15.7 million Brazilians were living in poverty despite the implementation of social welfare programs like Bolsa Família (family allowance) (Secretaria de Assuntos Estratégicos 2013). While this number is a vast improvement on the 43 million people living in poverty in 1992 and the 41 million in 2002, socio-economic inequality still plagues the nation (Secretaria de Assuntos Estratégicos 2013). Most impoverished Brazilian citizens depend on the public transportation system to get around and make a living. An increase that might seem small has the potential to significantly impact someone's finances and ability to survive between paychecks, especially considering recent inflation. This fact, along with disgruntlement in regard to misappropriated tax money and inadequate public services, motivated the Confederations Cup 
protests. Beyond a simple fare increase, these protests represented "mobility in the most literal of senses: the right to mobility which is also the right to the city, to collective decision-making, to opportunity, to justice" (Williamson 2013).

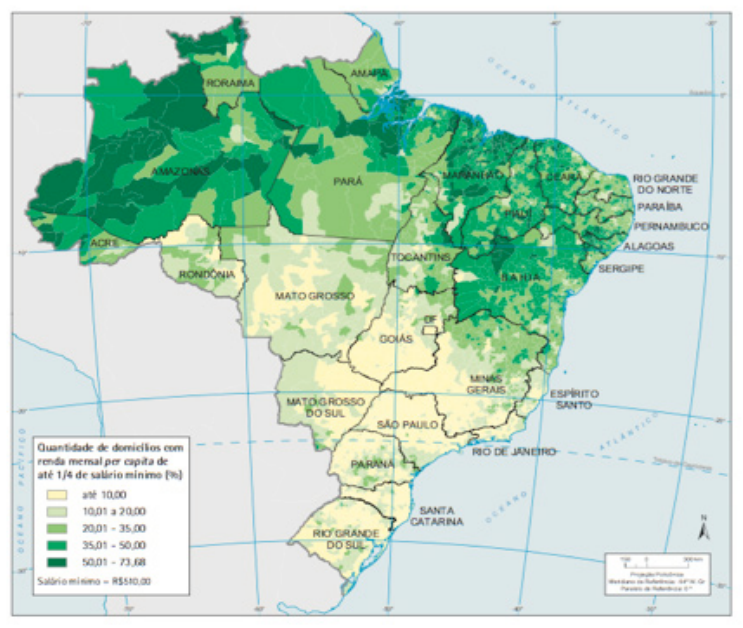

www.ibge.gov.br

Figure 4. Percentage of households in Brazil with a maximum per capita income of $1 / 4$ of a salário mínimo (minimum wage, which in 2010 by federal regulation equaled $\mathrm{R} \$ 510.00$ per month or $\mathrm{R} \$ 2.32$ per hour). Based on 2010 census data from IBGE (2011). Data shows that the largest concentration of low-income households is in the north and northeast regions of the country.

Yet, it was not just the marginalized poor taking to the streets in protest. Across the country, people of all ages, shades and socio-economic statuses were demanding a price readjustment. Leading the charge was a group of young, white college students called the Movimento Passe Livre (Free Fare Movement). These public demonstrations were organized via social media (primarily Facebook and Twitter), and were the largest since those calling for the impeachment of former president of Brazil Fernando Collar de Mello in 1992.
Demonstrations took place in over a hundred cities in Brazil and cities with a Brazilian diaspora around the world. The first demonstrations against the price were held in Natal, Rio Grande do Norte between August and September 2012, where protestors were able to convince the municipal government to reduce public transportation fares. Similarly, in March of 2013, protests in Porto Alegre, Rio Grande do Sul resulted in a judicial decision to reduce transportation prices (Zero Hora 2013). However, in MayJune 2013 the protests began to spread to other major municipalities. In Goiânia, Goiás, where the cost of a ticket was raised from $\mathrm{R} \$ 2.70$ to $\mathrm{R} \$ 3.00$, demonstrations became violently destructive after it was revealed that local bus companies were benefiting from tax breaks while continuing to increase passenger fares. A number of students were arrested for vandalism and civil disobedience after four buses were stoned and set ablaze. Nevertheless, the fare returned to its previous price after a preliminary injunction (O Globo 2013).

Marchers took to the streets because they "believe[d] the state [was] betraying citizens by turning over the economy to private interests" (Lesser 2013). In São Paulo, the fare increased from $\mathrm{R} \$ 3.00$ to $\mathrm{R} \$ 3.20$, even though the federal government exempted public transportation from the PIS (Social Integration Programs) and COFINS (Contribution for Social Security Financing) taxes, so that it would not contribute to ongoing inflation (Último Segundo 2013). This sense of betrayal incited more protests and vandalism. Given the tax breaks awarded to public transportation companies, adding twenty extra cents to the bus fare would only benefit the profits of private and government entities that own public transportation systems. Ironically, Brazilians "pay the highest taxes of any country outside the developed world (36\% of the GDP) and get appalling public services in return" (H.J. 2013). Chances are that the people paying the increased fare would never see their $\mathrm{R} \$ 0.20$ improve their transit experience. Nor would the fare change manifest itself as an increase in the salaries of bus drivers, train conductors, or maintenance 
personnel. What's more, the whole country had seen fare increases the year before and Brazilians seemed to be fed up with not seeing a return on their investment.

The protests and transportation strikes of June 2013 show that samba e futebol (samba and soccer) are not the only things that have the power to unify the Brazilian people-though both are intertwined with the period's civil unrest. While the demonstrations in Brazil began as a response to the $\mathrm{R} \$ 0.20$ increase in bus, train, and metro fares, they quickly grew to incorporate other grievances. More than twenty cents, the protests of 2013 represented a stand against government corruption and injustice. They represented a stand for a more direct, participatory democracy; "The public does not accept more state support for the national team than for national citizenry" (Lesser 2013).

A major point of contention was citizens' dissatisfaction with public social services and the misappropriation of public funds in preparation for major sports events, including the 2013 Confederations Cup, the 2014 World Cup, and the 2016 Olympics. With a final estimated price tag over US\$ 11 billion (nearly three times what was spent by South Africa in 2010), the 2014 World Cup in Brazil was the most expensive since the competition began 85 years ago (Koba 2014). Much of the infrastructure promised for the Copa that would benefit host cities in the long-term, including expanded airports and public transportation systems as well as twelve new or renovated soccer stadiums, was not completed in time for the games. Moreover, approximately US\$ 3.6 billion of the money used for the stadiums came from taxpayer money (Neely 2014). It is not hard to see why people would take to the streets to demand better-funded transportation, healthcare, and education when so much money was spent-money that could have funded improvements in public education, public transportation, and public health, such as the construction of 123 hospitals (BOL 2013). Notably, the new stadiums will not provide sustainable revenue. What's more, a large portion of the population was unable to afford tickets to the matches. Given the percentage of impoverished Brazilians who are also of African descendent (illustrated by figures 1,4 , and 5), the lack of racial diversity seen in the stadium stands was to be expected, but was still shocking considering how Brazil advertises itself a rainbow nation (Araújo 2014).

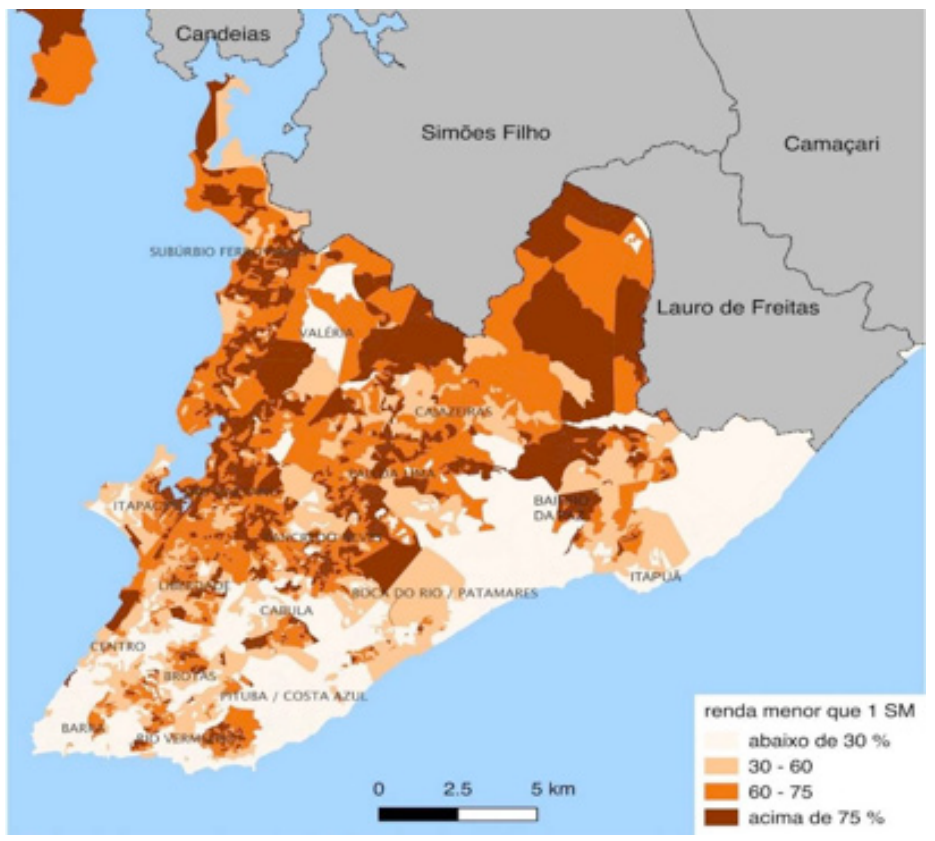

Figure 5. Percent of households in Salvador with a per capita income less than one salário mínimo based on 2010 census data from IBGE processed and mapped by Inaiá Maria Moreira de Carvalho and Gilberto Corso Pereira $(2015,17)$. Data shows that less than $30 \%$ individuals living closest to the coast live with less than one salário mínimo. As illustrated by figure 1 , the majority of these people self-identify as white.

Because I arrived in Salvador at the beginning of June 2013, I was able to witness civil society express its discontent first hand alongside the fervor around the Confederations Cup. I watched their objectives shift and grow as citizens realized the power they held. Buses were the perfect place to people-watch and to experience firsthand why citizens were protesting. Almost everyday in June, I rode the bus from Itapuã to downtown Salvador for over an hour, experiencing for myself why people would take to the streets over twenty cents. 


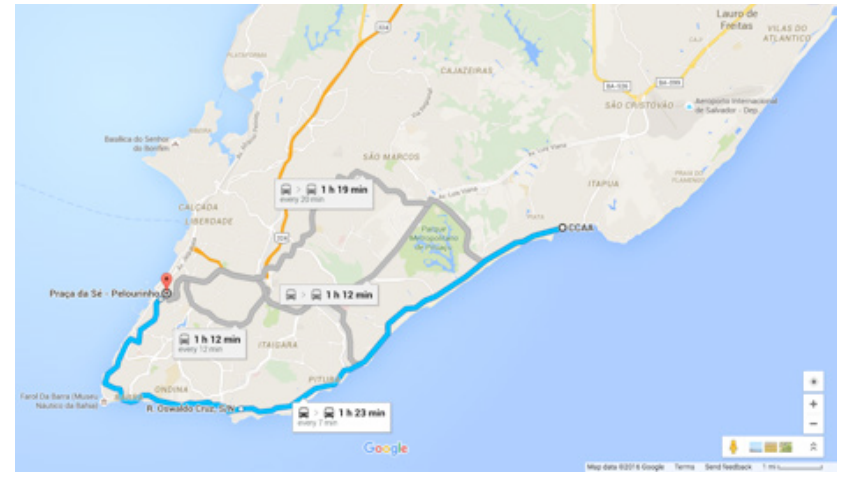

Figure 6. Map depicting bus route from my home stay in Itapuã to Pelourinho. The coastal bus route originates at Salvador's airport, passes through the majority of its wealthy, white neighborhoods, and terminates at Praça da Sé in the historic city center. This is the same bus route that most Confederations Cup and World Cup tourists utilized in the summers of 2013 and 2014. Screenshot taken from Google Maps.

I saw people who in the long run probably would be unable to afford the R 0.20 increase. Unlike in Rio de Janeiro and São Paulo where the public transport systems are integrated, the fare change in Salvador would mean a single ride would cost $\mathrm{R} \$ 3.00$, without the possibility of a reduced fare transfer to other bus routes. During my bus rides, I saw stoic fare collectors and overworked bus drivers; people on their way to and from work; students who pay full price for public transport; and vendors, poets, preachers, and family members of individuals with serious illnesses, all hoping to get a real (unit of Brazilian currency) or two from a couple of hungry or sympathetic passengers. Most bus riders live below the poverty line. Most of these people are black. None of them would benefit from the fare hike. Giving up an extra twenty cents would not get them where they are going any faster, nor would it fix the broken stop-request-buttons. An increase in transportation costs would not complete Salvador's stalled metro project, thirteen years in the making. The price increase would not keep passengers from being victims of petty theft while traveling or from ducking bullets when shots are fired near a bus stop.
At my homestay with Izabel during the summer of 2013, we would watch television and switch between channels: on one we would see people excitedly cheering on the Brazilian national soccer team, on the other we would see Brazilians citizens being violently corralled by military police in the streets around the country. As I watched, a similar back and forth began to emerge as a dilemma within me: to join in or to sit on the sidelines from the comfort of the living room as a revolution unfolded before me on the television screen. Despite the call of protesters singing, "Come to the streets," I made the choice to observe from a distance.

In this intense and exciting time of protest, I could not help but think about how these public demonstrations would shape my research. While I had come to Brazil with the intention of examining the relationship between Afro-Brazilian percussion and black identity formation, community engagement, and political activism, the June protests complicated my understanding of that relationship. Historically, many blocos afro have tried to bridge the gap between cultural production and political activism by raising black consciousness. Because Bahia has the highest concentration of African descendants in Brazil, any political movement has the potential become a part of the black movement. Yet, demonstrations in Salvador were not perceived as such. Instead, they were part of nationwide movement led by white youth that distinguished itself in Salvador by employing elements of Afro-Bahian culture. A year later in a 2014 interview, Ubiratan, the leader of a local percussion-focused nonprofit in one of Salvador's poorer, periphery neighborhoods, pointed out: 
Of course we have a lot of barriers; there is still a lot of discrimination. There are times when we are excluded. Unfortunately, people want to use our culture, but don't want us to be empowered by it. Generally, a lot of people take advantage of us; they use our image to make a profit on us. When there is a profit to be made, they choose the price. When it's advantageous they use us, but usually blacks don't benefit from this. Those who are benefiting are the whites. [...] I think we have to be grateful to have the opportunity to fight to be valued. This is our struggle; strengthening the culture is part of our work here [at our NGO] as well.

Speaking to this oppressive form of cultural appropriation based in the multiculturalist rhetoric of Brazilian nationalism, Ubiratan further illustrated the complexities of this burgeoning social movement's deployment of culture-as-resource. During the Confederations Cup I encountered protests organized by primarily middle-class, white university students rather than a movement propelled by re-Africanized Bahian cultural groups, as seen in previous decades. Although many of these protesters would not identify themselves as preto or pardo, they invoked blackness conceptually through the use of the region's black-identified music.

On June 20, 2013, just a few days after the opening of the FIFA Confederations Cup, protests in Salvador escalated, following the example of demonstrators who took to the streets in the southeastern cities of São Paulo and Rio de Janeiro. Singing the Brazilian national anthem, people amassed at Campo Grande (big field), the traditional stage of carnival in Salvador, and attempted to march to Salvador's newly remodeled Fonte Nova stadium during the Nigeria versus Uruguay game. Although protestors were stopped before they made it to Fonte Nova by police officers armed with rubber bullets and teargas bombs, they did encircle one of the FIFA vehicles and delayed its arrival to the stadium (Barros Neto 2013).
Two days later, on June 22, 2013, nearly 20,000 citizens, primarily youth, took to the streets in the early afternoon. The Italy versus Brazil match was scheduled to be played in the Fonte Nova arena later that evening and I went to watch it with Izabel at her friend's house. Forty-eight hours prior, military police had been deployed throughout the city when FIFA officials threatened to cancel the match after plans for the march to cut off a major highway appeared in newspapers and on social networking sites (Hafiz 2013). Protestors once again gathered in the center of the city at Campo Grande and over the course of the next six hours they made their way towards the outskirts. As they walked, marchers chanted "Salvador vai se unir! A tarifa vai cair!" (Salvador will be united! The bus fare will fall!), and called out to observers to join their cause (Hafiz 2013).

Though it began peacefully, the demonstration ended in violence when a police barricade confronted marchers. The scene soon looked like a war zone. Even as they pleaded with officers not to take violent action, civilians were shot with rubber bullets and teargas bombs were thrown into the crowds (Hafiz 2013). After the Italy-Brazil game had finished, the son of Izabel's friends came home. He and his girlfriend, both white and in their twenties, had been part of the protest and were shot at with rubber bullets. As the son spoke, his frustration with the unchecked police violence and the larger situation of corruption and inequality was as vivid as the violet bruises blossoming on the pale skin of his arm. Later that night when I arrived home, I checked the Facebook pages organizing protests and came across an image of a black man holding a sign from the protest in Salvador quoting Afro-Brazilian poet Gullewaar Adún. It read: "Por que as balas de borracha na pele branca comove mais que as balas de verdade que mata a população negra todos os dias?" (Why is it that rubber bullets hitting white skin cause more of a commotion than the real bullets that kill the black population every day?) 
In the following section of this article, I provide an excerpt from my field notes and thick description of the demonstrations in which I unwittingly participated during the 2013 Confederations Cup. Importantly, I give special attention to the use of music and percussion in the protests in Salvador.

Thursday June 27, 2013

Today when I awoke I thought it would start just like the rest of my days have in Bahia. I thought I would wake up, get something to eat, go to my drumming lesson, walk around Pelourinho for a while, and then take my bus back home to Itapuã. However, today had other plans for me. I went to Campo Grande with a friend for lunch at Sorriso Maria (Mary's Smile), a little mom and pop lanchonete (lunch restaurant). It had just started to drizzle and people were beginning to crowd under the building's overhang on the corner. There were no free tables inside, so the waiter sat us down with a man fiddling with a professional-grade digital camera and a Macbook Pro, proclaiming that he was gente boa (good people). After smiling and nodding for us to sit, the first thing this man asked us was if we were in Campo Grande for the protest. It was around 13:30 and I told him we were just there to have lunch. When I asked him what time the protest would start, I discovered that within half an hour, Campo Grande would be full of young protestors from the Movimento Passe Livre. It seemed that after weeks of trying not to get involved I had walked right into the middle of a protest.

Our lunch companion was a photographer for the Bahian newspaper A Tarde (The Afternoon) and had been covering the recent events and protests of the Confederations Cup in Salvador. After we finished our lunch, we said goodbye and wished him luck. The protest had started and since the buses were no longer running, I had to walk to Pelourinho for my drumming lesson with Bira. The closer I got to Praça da Sé (Square of the [Holy] See), the more military police I saw amassing on foot, lining the streets on motorbikes, sitting on the backs of pickup trucks, and flooding out of camouflage armored buses. The batalhão de choque (shock battalion) had arrived and I assumed they would be going to Campo Grande to meet the protestors.

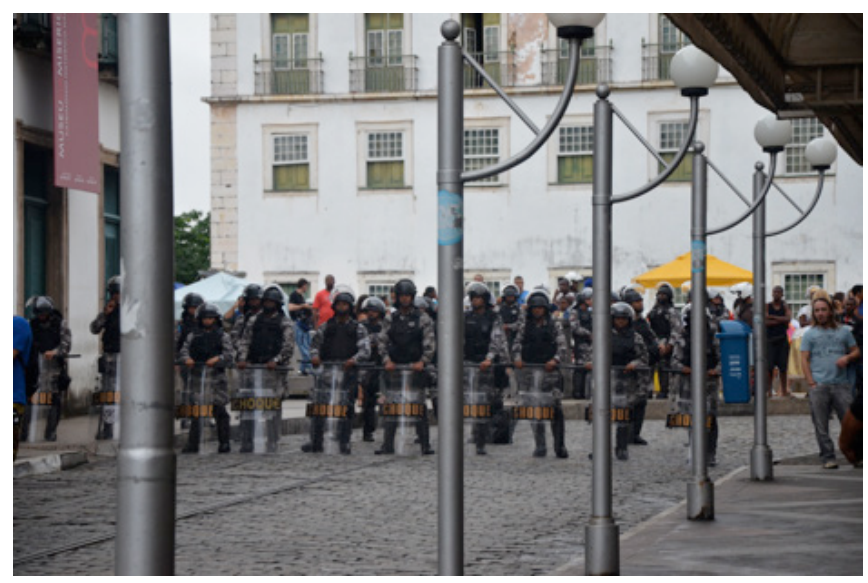

Figure 7. Shock battalion of the military police await the arrival of protestors in Praça da Sé. Photograph by author.

Naively, I thought that by the time my drumming lesson was done, the police would be gone, the protest would be over, and the buses would be running again. I was wrong. Today would be the day that I accidentally joined a protest. I had two options: to stay where I was until the protest escalated and was disbanded or to walk through the crowd to find a bus home while everything was still peaceful. I went with the latter. Almost as soon as I started walking in the direction of the protestors a man walking the opposite direction said to me, "Tá em guerra menina, não vá!" (It’s war, girl, don't go!). 


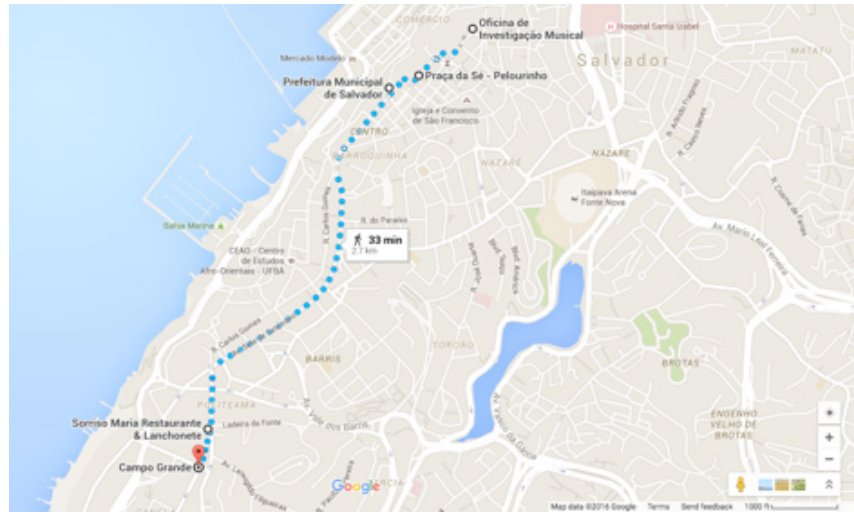

Figure 8. Map of the route I walked from lunch at Sorriso Maria to my drumming lesson with Bira at Oficina de Investigação Musical (Shop for Musical Investigation) and back from the Praça da Sé bus stop to the bus stop at Campo Grande. This map also shows the proximity of the protests outside the prefeitura to Fonte Nova stadium where the soccer matches were held in Salvador. Screenshot taken from Google Maps.

As I made my way to the back towards the Praça da Sé bus stop, I could hear the protestors chanting "Eu quero, eu quero, eu quero passé livre sim!" (I want, I want, yes I want a free pass). Soon I could see them surrounded by the tight-lipped police officers. The protestors had marched from Campo Grande to Praça da Sé to stand outside of the prefeitura (city hall), calling for free bus passes for students, an end to corruption, and better education and health systems with chants and picket signs. There were even signs against Brazil's largest media outlet, $O$ Globo, which was not accurately covering the nationwide protests. Demonstrators called out to onlookers and passersby, "Vem, vem, vem pra rua ver que a luta cresce!" (Come, come to the streets and see the fight grow).

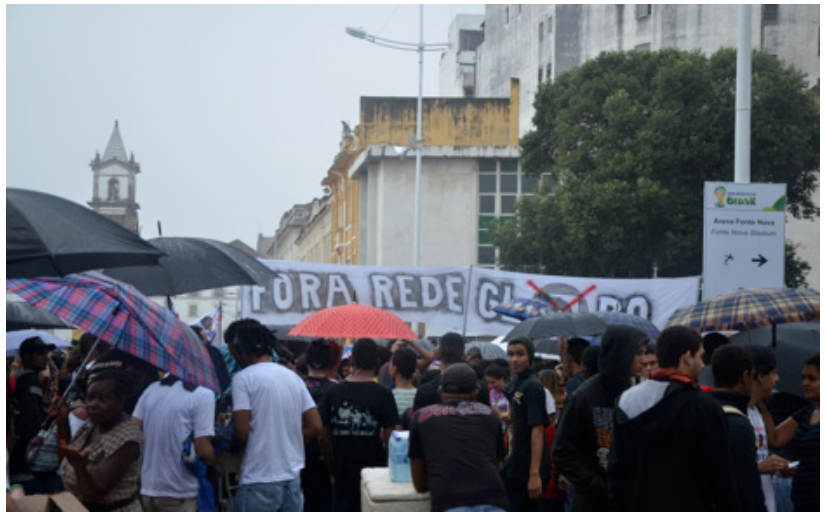

Figure 9. Protestors in Salvador gather outside of city hall with a sign that reads "out with the Globo network." Photograph by author.

About halfway through the crowd I came across a make-shift bloco afro, which happened to include Bira's daughter. There were young people playing snare and bass drums, along with plastic tubs and jugs tied around their waists. I had arrived in Salvador wondering about the relationship between Afro-Brazilian percussion and political activism, and here it was-perfectly not how I anticipated it would be. The expectation that the blocos afro would operate in the present, disrupting the status quo just as they had in the history books I had read was unrealistic; organizations evolve and shift focus. Additionally, I had erroneously surmised that Afro-Brazilian percussion would simply be a tool used in community-based activism and citizenship education, emphasizing ethno-cultural affirmation. In that moment, the difference between reading about something and thinking you know a little about it, and meeting that same thing in the field functioning completely differently from what you expected, was thrust upon me. The cultural influence of the blocos afro on the protest-scape of Salvador seemed self-evident. If this was war, as the man had shouted to me, where people were fighting for their rights, it seemed appropriate that there was a drum corps present continuing the legacy of the first blocos afro. 


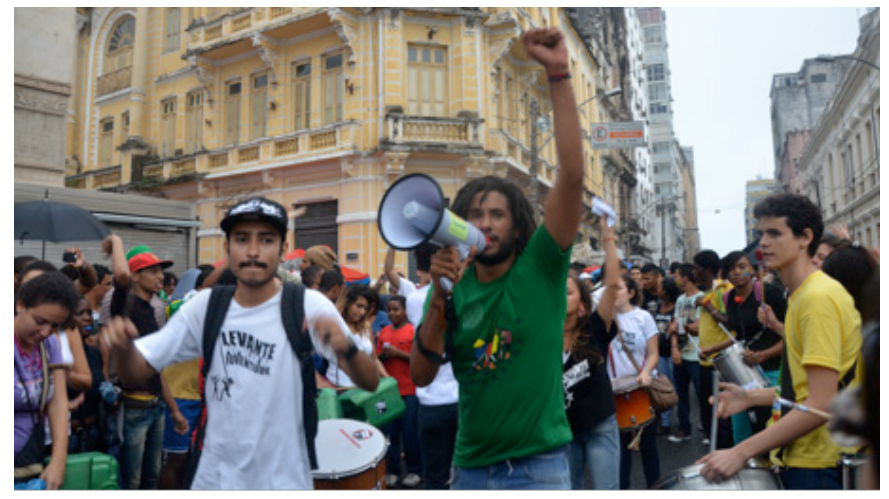

Figure 10. Protestors playing drums and plastic and metal containers. Photograph by author.

In the streets there was no division between "performer" and "spectator." No one was wearing a uniform with a specific bloco's logo, although some had shirts associated with the Movi-mento Passe Livre. Everyone was chanting and there was a sense of ordered disorder. Those individuals with instruments played in unison, but they were also free to play or not play. The main goal seemed to be to drive on the chanting as opposed to giving special attention to the instrumentation or rhythmic variation.

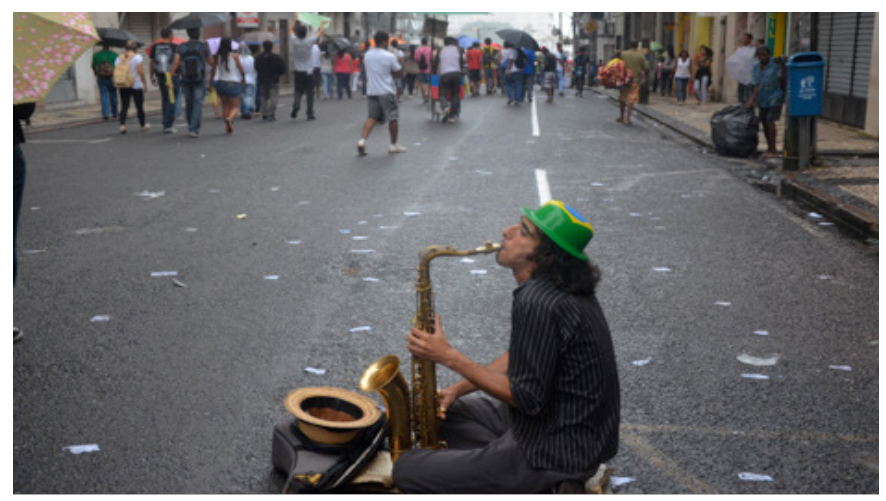

Figure 11. Saxophonist plays in the street as protestors march on. Photograph by author

As I walked by, I took a few photographs and kept moving through the crowd. It was not until I had walked all the way back to Campo Grande that I found a bus to take home. Later that night, while watching the news with Izabel and her mother, it was reported that the protest downtown had gotten violent and the police had used teargas bombs on the protestors.

Sunday June 30, 2013

While waiting for my friends to arrive at Campo Grande, I decided to photograph the Movimento Passe Livre protestors.

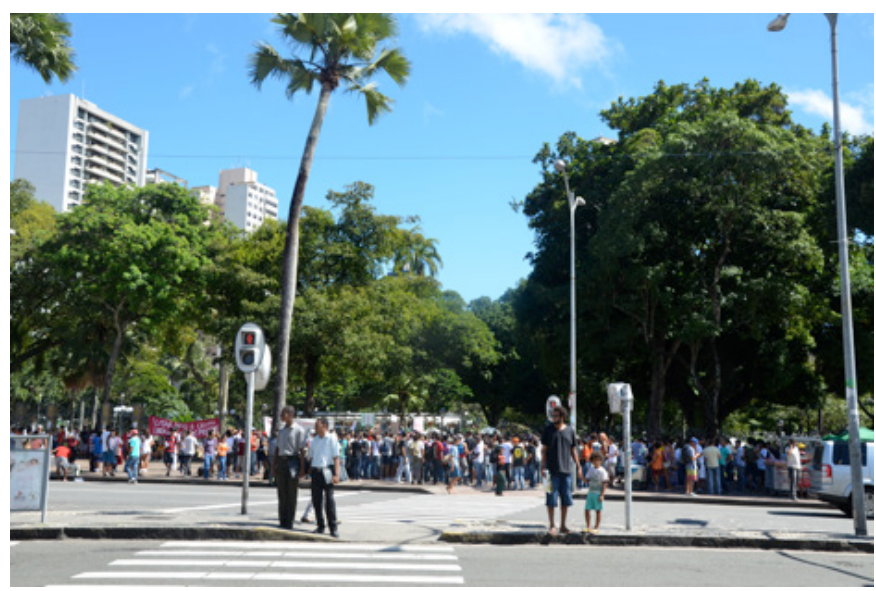

Figure 12. Demonstrators amass in Campo Grande. Photograph by author.

Many people were carrying Brazilian flags or wearing green and yellow soccer jerseys. There were also some individuals wearing the white Guy Fawkes mask from the film V for Vendetta that have come to symbolize resistance to government oppression. Others wore shirts that read: “Don't hit me!" Evident in the protestors' chants and in their signs was a call on the government to use tax dollars and other public monies to invest in them as members of Brazilian society through education and health, rather than investing in an excess of new soccer stadiums for the World Cup. Picket signs also demanded a "free pass" to end racism and homophobia (a reference to the proposed "Cura Gay," or gay cure legislation), the right to take to the streets and protest, an end to police brutality. 


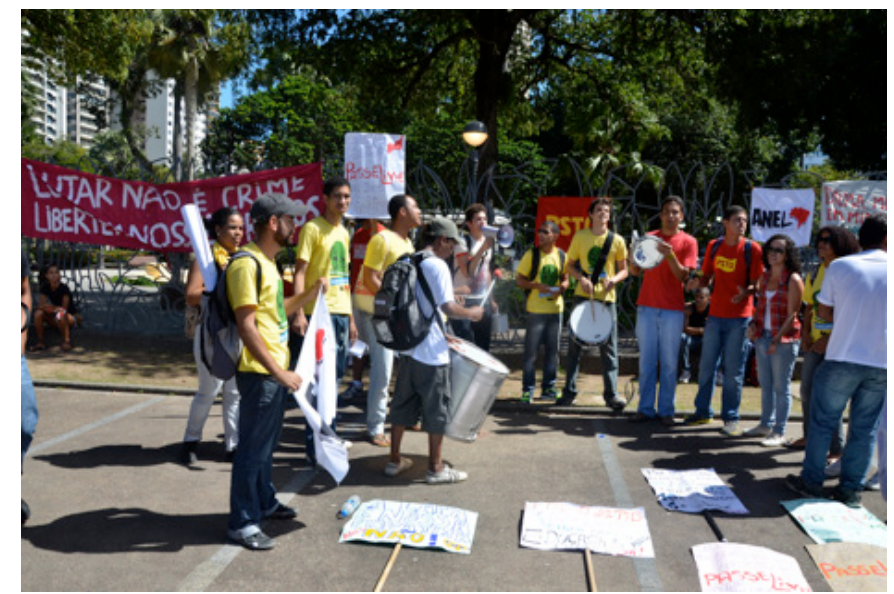

Figure 13. Protestors with drums assemble and chant in Campo Grande. Photograph by author.

People were jumping, clapping, chanting, and shouting their grievances. "Da Copa, da Copa, da Copa eu abro mão! Eu quero investimento na saúde e educação" (The Cup! The Cup! I can do without the Cup! I want investment in health and education!). Similar to the previous protest, there were two makeshift blocos afro comprised of surdos (bass drums), caixas (snare drums), and metal and plastic containers. These two groups of percussionists functioned as an organizing force behind the songs and chants of the protestors. They alternated between using a basic clave beat (played by all instruments present) and the samba-reggae rhythm (with each instrument playing a particular role) as a musical basis for the chants. Eventually, as more people began to arrive in Campo Grande the two percussion ensembles merged and played the samba-reggae rhythm together while protestors sang "Vem Pra Rua" (Come to the Streets).

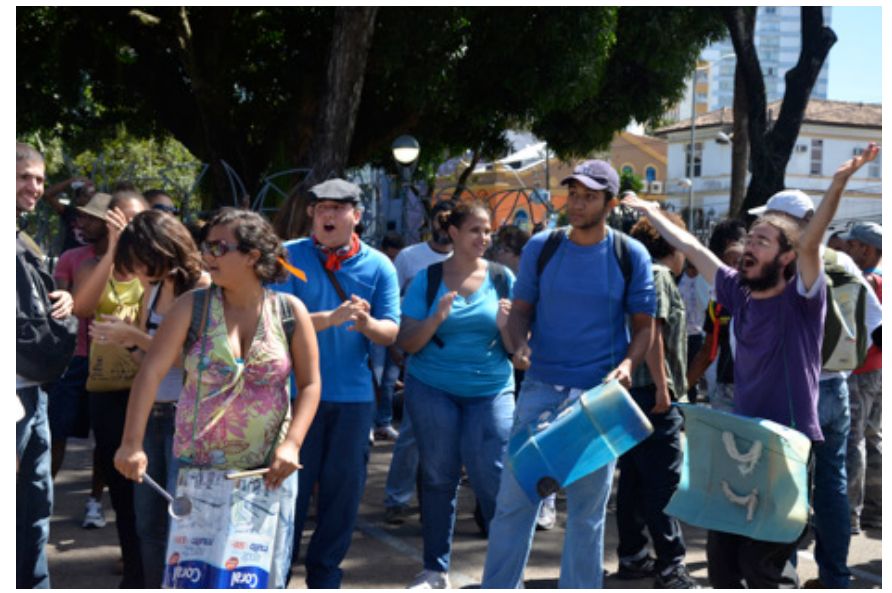

Figure 14. Protestors chanting and using metal and plastic bins as percussive instruments. Photograph by author.

\section{Social Media and The Sound Track of Protests in Brazil}

Music has always been a conduit for change in Brazil. From activists and nonprofits associated with the blocos afro uniting Salvador's black community, to political authorities and private institutions promoting their interests, music has been used to mobilize the masses. Historically, Afro-Brazilian music has played a significant role in the development of Brazilian national identity at the hands of the government-a prime example being the acculturation and whitening of samba music beginning in the 1930s (McCann 2004). Incidentally, those who oppose the actions and policies of the government have also employed music. This was especially true during the military dictatorship that lasted from 1964 to 1985. Figures such as Bahians Caetano Veloso and Gilberto Gil were even exiled for their outspoken musical critiques of the government. Even so, the meaning behind their songs still resonates with listeners today. This is equally true with any song that challenges an oppressive power regime. Music is protean, able to traverse dividing lines of race and class and embody multiple meanings. With the rise of the Internet, music has become even more accessible and is widely shared via social media. This is quite significant considering the important role social media played in how protests were organized nationwide. In this section, I will 
analyze the song "Vem Pra Rua" (Come to the Streets) and its social media presence within the context of the June 2013 protests.

Originally written by Henrique Ruiz Nicolau as a jingle for a Fiat advertising campaign during the FIFA Confederations Cup of 2013 and performed by Marcelo Falcão-the lead singer for the reggae-rock band O Rappa, known for its socially conscious lyrics- "Vem Pra Rua" quickly became the anthem of protestors. Interestingly, despite its commercial beginnings, the song began to take on a life of its own and was appropriated by protestors (RomaFiat RJ 2013). In the words of Fiat's marketing director João Ciaco, "The song doesn't belong to Fiat anymore, it's the people's" (Scheller 2013).

Come on let's go to the streets

You can come cause the party is yours

Cause Brazil is going to be big

Greater than ever before

Come go with us

Come cheer and show support, keep moving forward

Leave home, come to the streets

To the largest grandstand of Brazil

Ooooh

Come to the street

Because the street is Brazil's largest grandstand

If this street were mine

I would order it tiled

Everything in green and yellow

Just to see the entirety of Brazil go by

Ooooh

Come to the street

Because the street is Brazil's largest grandstand

Come to the street!
As the theme song for the 2013 protests, "Vem Pra Rua" can be interpreted as a metaphor for Brazilian citizens' engagement in the democratic process. Each time I heard "Vem Pra Rua" being chanted, protestors carrying drums and other percussive objects played the same underlying driving rhythm heard in the recording. The song begins with an open invitation for listeners to come out into the streets. In its original commercial context, the "party" referred to in the second line probably implies a celebration for the World Cup. However, within the context of a demonstration, asserting that "you can come cause the party is yours" reaffirms protestors' right to physically disrupt the status quo, to claim the space at a "party" (read: democracy) that should cater to them, and to add their voice to the conversation on citizens' rights. Because Brazil has always been the "country of the future" (Zweig 1941), it is through this civil engagement, occupation of space, and airing of grievances that protestors see Brazil as becoming "greater than ever before."

The second and third verses also carry the weight of multiple meanings. On the surface, listeners are invited to leave home and come cheer in the streets as they support the Brazilian national team. However, as illustrated in the description of demonstrations in the previous section, protestors used these lines to encourage onlookers to join and support the growing movement. While the phrase "bola pra frente" literally translates to "ball to the front" and conjures the image of a soccer player kicking a ball forward, figuratively it is used as a motivational phrase to encourage persistence. The line "leave home, come to the streets" emphasizes the sense of transition from a complacent collective contained within private space to dynamic group of protestors a in public space taking direct action. This is supported by the singer's desire to see the street tiled in green and yellow as fans/demonstrators go by in the following verse. 
As I previously mentioned, most Brazilians were unable to purchase tickets to watch matches in the new stadiums and the faces in the stands were largely white (Araújo 2014). This makes the line "the street is Brazil's largest grandstand" particularly striking. During both of my summers in Brazil I watched most matches on the streets of Pelourinho with the preto and pardo masses with the pulse of the bloco afro Olodum vibrating in my feet and fans' cheering voices filling the air. The street can in effect be seen as a set of bleachers. Yet, unlike those in the stadiums, the street is inclusive; everyone, including impoverished Afro-Brazilians, has access this "arquibancada." It is in the inclusive environment of the street where the people are able to assemble and make their voices heard through protest. The street is where people believe they have the potential to change Brazil.

In addition to music, in the protests of June 2013, social media played a significant role in terms of demonstration organization. This is far from surprising considering that Brazil is the second largest user of Facebook and Twitter in the world and the fact that $85 \%$ percent of the population is comprised of highly sociable urban youth (41.5\% are under the age of 25) (Williamson 2013). Because "Vem Pra Rua" resonated with so many Brazilians, the phrase exploded on the Internet. What started as a jingle-turnedprotest-song took on another life and meaning. The hashtag \#VemPraRua was used prolifically to share information, photographs, memes, and videos related to the protests. A group of organizers came together to create a website called vemprarua.org which compiled in one place information on planned protests all around Brazil. Thereafter, vemprarua.org evolved to be a comprehensive portal with a reach beyond the act of public demonstration. The site includes and archive of photos and videos from the protests. Importantly, because of recent political scandals, vemprarua.org and other social media platforms became active again in the wake of nationwide protests on March 15, 2015 against President Dil-ma Rousseff and corruption within in the Brazilian government. These protests continued throughout 2015 and early 2016.
Subsequently, in April 2016 the Brazilian National Congress initiated the process for President Rouseff's impeachment; on August 31, 2016 she was removed from office for breaking budget laws. For better or worse, by combining Hanchard's "culturalist" practices, such as using Afro-Brazilian percussion in protests, with strategic mobilization via social media, Brazilian youth have been able to incite some institutional change.

Not only were Facebook, Twitter, and Instagram major sources of information for people who wanted to learn more about the movement and get involved, but they also served as a platform for the movement to gain direction. A major complaint of government officials and mass media outlets was that the protestors had no clear demands. As a result, on June 18, 2013 a collective named "Anonymous" released a video on YouTube entitled "Anonymous Brasil-As 5 causas!" (Ascinco Causas).

In one minute and forty-five seconds the narrator of this short video-wearing a $V$ for Vendetta Guy Fawkes mask-asserts that the protests are a good place to begin building a new Brazil. According to Anonymous, lowering the cost of public transportation is not enough, so the collective suggests five further reasons why people would be speaking out, asking for collaboration, and adherence to the causes. The Five Causes call for the following: 1) rejection of PEC 37, a proposed amendment to the constitution that would give the police exclusive power to conduct criminal investigations and limit the power of federal prosecutors in the Ministério Público (Public Ministry) to investigate crimes. The amendment could potentially hinder attempts to incarcerate corrupt police officers and politicians; 2) the removal of Renan Calheiros from his position as president of the Brazilian National congress; 3 ) investigation and punishment for irregularities in the work done in preparation for the World Cup by the federal police and the Ministério Público Federal; 4) a law making corruption in congress a heinous crime; and 5) an end to the privileged forum (Ascinco Causas 2013). 
Less than 24 hours after its release, the video went viral with over a million views. Within a few days it had been re-posted about 1000 times on other YouTube channels and video sites. This rapid dispersion on the Internet, and subsequent attention by mass media sources, allowed the "Five Causes" to become commonplace in protests in different parts of the country.

This flurry online activity spurred a response from the Brazilian government. The following week, on June 24, President Dilma Roussef held a meeting with mayors and governors from all over the country and proposed five pacts and a referendum in response to the demands of protestors. These were: 1) fiscal responsibility and control of inflation, 2) political reform and eradication of corruption, 3) improvement of public health, 4) improvement in the quality of public transportation, and 5) improvement of the education system (Mendes, Costa, and Passarinho 2013). When the senate approved a bill making corruption a heinous crime on June 26, it seemed as if change was coming to Brazil.

However, the jeitinho brasileiro (Brazilian way) can be counterintuitive. In early July 2013, the Brazilian government announced that royalties accrued from petroleum drilling in the pre-salt layer off of the coast of Brazil would be used to fund improvements in the public education and health systems (Senado Federal 2013). While Brazil has taken steps to reduce the effects of global climate change by decreasing deforestation in recent years, this new oil policy intertwining public services and government business interests has the potential to not only affect Brazilian citizens, but the entire world. By funneling oil money into revitalizing public service, the Brazilian government has put its citizens in a position where they are supporting an initiative that will be to their own detriment in the long term. In this instance, one cannot separate the struggle for citizens' rights and the struggle for environmental protection. It seems the country took one step forward to take two steps back.
In an interview with one of my informants during my second summer in Salvador, I asked this teenage Afro-Brazilian musician about changes in Brazil after the June 2013 protests. Though her parents had kept her from participating in the demonstrations because of police brutality, she vehemently supported the uprising, saying:

Brazilians only do nice things for those from abroad because if the Copa weren't happening, everything would continue as the same shit. The Copa finished and everything went back to normal with only a few renovations of the space, but everything is the same shit. For me nothing changed. The hospitals continue to be a shit, the transportation continues to be shitty, and everything continues to be shit-education. It's all the same, but when the [foreign] people were here, the gringos, everything was all nice, everything was cool. Now everything is the same shit, back to reality. [...In the protests] I think for the first time the people knew what they were doing; they realized [the government] was just doing [those improvements] for the Copa. It's more than a ten-cent increase in transportation fares. I think it was because the people woke up to what was happening.

Given my experiences during the protests in Salvador, I am inclined to agree with her. Not two days after the games were over, the military police who had been standing guard at all of the major bus stops frequented by tourists during the World Cup were gone. Everything had changed, and yet everything was the same. 


\section{Conclusion}

Over the course of this paper, I have argued that Brazilians use music as a tool to assert their claims to rights, both in the streets and through song. To demonstrate the importance of music in the process of claiming citizenship rights, I pointed to an example from my fieldwork. The protests of June 2013 following the in-crease in transportation fares across the country illustrated how music is used in direct action. Not only did protestors assemble make-shift percussion ensembles and invoke blackness by playing the rhythms of blocos afro, they also employed a shared musical vocabulary based on the appropriation of the Fiat jingle "Vem Pra Rua" and other chants posted on social media. Considering the historical role of music in national identity formation, it would seem that for Brazilians, music continues to be a shared language able to mediate across racial and class lines. Moreover, as anthropologist Maureen Mahon affirms, "music [...] is a medium of expression that involves the formation of social relationships, the construction of identity, and the development of collective practices" $(2004,102)$. Building on the ideas of ethnomusicolo-gist Thomas Turino, she writes, "As both a cultural product and social process, music brings people together, articulates who they are, furthers their political goals and gives meaning to their lives" (Mahon 2004, 102; Turino $1993,5)$. From the use of Afro-Bahian rhythms to the cooption of a commercial jingle, the protests of June 2013 illuminate how music in Brazil serves as such a multi-faceted platform.

Within this framework of music as a unifying entity, the use of Afro-Brazilian percussion and the samba-reggae rhythm at the protests is especially notable. This music that was being used is black-identified and inseparable from Afro-Brazilian subjectivi-ty. When asked about the use of Afro-Brazilian percussion in the 2013 protests, my drumming instructor Bira believed it had to do with the traditional usage of war drums in Africa and Europe and the fact that Afro-Brazilian rhythms resonated with the people of Salvador.
He said:

There was always music with instruments as protest, now I think this is a result of this [historical practice...]. The blocos a fro have an influence even in this, in the demonstrations because [the protestors] learned a little of this [Afro-Brazilian history]. Inasmuch no one is going to play a [military] march, like they played in the streets in the old days, they are going to play the percussion of blocos afro or samba. The bloco afro became trendy; it could be played fast or slower. It's in the [collective] memory [...] if it wasn't they would play something else.

Whether consciously or not, as a part of their demonstrations the young Bahian protestors of all racial identities felt inclined to utilize rhythms whose history is inseparable from the struggle of preto and pardo soteropolitanos (people of Salvador) to value their blackness, to be included in segregated carnival practices, and to assert their right to public services. Because marginalization in Brazil is so strongly associated with blackness, it's fitting that a black form of cultural expression such as percussion would be employed to contest hegemonic power in an instance when the masses felt alienated from government policies.

Here, I return to the central questions posed at the outset of this paper: What is the relationship between Afro-Brazilian percussion, black identity, and youth activism? Moreover, how have groups of young people employed music and social media, in an effort to lay further claim to their rights? The relationship between the three entities in the first question is embedded in the local, given Salvador's racial composition and history of cultural activism. The current generation of soteropolitano youth have embraced the legacy of community-based and black-identified rhythmic resistance established by the blocos afro in the 1970s and 1980s. 
The World Cup protests were built on the backs of the marginalized, their music used to open space for activism. As my informant Ubiratan pointed out, Afro-Bahian culture has been consistently appropriated and commoditized without necessarily benefiting the black communities that birthed the culture. While protestors demanded accountability of government officials and improvement of public education and health, it remains to be seen if their activism will impact the communities who have long lived without consistent access services guaranteed by the Brazilian constitution. As for the second question, youth utilized music and social media as tools to claim space-physically by occupying the streets and virtually to illuminate the issues, communicating their demands and organizing the masses on the Internet. Because it is an aural medium, protest music-whether commercial or 'organ-ic' in origin-could be found in both places, adapted to best serve the agenda of the demonstrators.

In closing, I would like to return to Frederick Moehn's application of audiotopia-the metaphorical space that music helps us imagine and that has the possibility to be a safe haven between factions of a stratified society - to Brazil. Moehn suggests that the ambiguous musical space where culture meets class, history, violence, and the state can be a refuge from both or either of the two Brazilian realities. Or, the audiotopia can be seen as a place where mobilization can take place (Mohen 2011). Based on my fieldwork and the audiotopia created by the Confederations Cup protests, I know both to be true. Music is simultaneously a currency, an escape, and an apparatus. The citizen has the power to decide which path to take. 


\section{Acknowledgements}

I am eternally grateful for the individuals and institutions that made this article possible. Em particular, eu agradeço profundamente aos meus informantes e amigxs brasileirxs que compartilharam suas histórias e experiências comigo-me ensinaram mais que pudessem saber. Finally, I want to thank the Mellon Mays Undergraduate Fellowship for funding my research and providing crucial mentorship that has shaped the beginning of my academic career; my thesis advisors at Brown University, Paja Faudree and Joshua Tucker, for helping me bring this work to fruition; and the Journal for Undergraduate Ethnography team for making its publication possible. A luta continua.

\section{References}

Araújo, Felipe. 2014. “The Lack of Black Faces in the Crowds Shows Brazil Is No True Rainbow Nation.” The Guardian, July 1. http://www.theguardian.com/commentis free/2014/jul/01/brazil-black-faces-crowd-rainbow-nation-world-cup.

Ascinco Causas. “Anonymous Brasil - As 5 causas!”. Filmed [June 2013]. YouTube video, 01:45. Posted [June 2013]. https://youtu.be/v5iSn76I2xs

Avelar, Idelber, and Christopher Dunn. 2011. Brazilian Popular Music and Citizenship. Durham: Duke University Press.

Barros Neto, Nelson. 2013. "Protesto em Salvador começa contra a Fifa e tenta chegar a Fonte Nova." Folha de S. Paulo, June 20. http://www1.folha.uol.com.br/ esporte/folhanacopa/2013/06/1298342-protesto-em-salvador-come ca-contra-a-fifa-e-tenta-chegar-a-fonte-nova.shtml.

BOL. 2013. “O Que Poderia Ser Feito Com o Dinheiro Dos Estádios Da Copa.” BOL, March 31.http://fotos.noticias.bol.uol.com.br/esporte/2013/04/04/o-que-poderia-ser-feitocom-o-dinheiro-dos-estadios-da-copa.htm?fotoNav=1.

Collins, Patricia Hill. 1986. "Learning from the Outsider Within: The Sociological Significance of Black Feminist Thought." Social Problems 33 (6): S14-S32.

Du Bois, W.E.B. 1903. The Souls of Black Folk. Chicago: A.C. McClurg \& Co.

Hafiz, Jihan. "Salvador Protests Attempt to Disrupt FIFA Game in Brazil". Filmed [June 2013]. The Real News Network video, 09:27. Posted [June 2013]. http://therealnews.com/t2/ index.php?option=com_content\&task=view\&id=31\&Itemid=74\&jumival=10364.

Hanchard, Michael. 1994. "Black Cinderella?: Race and the Public Sphere in Brazil." Public Culture 7 (1): 165-185.

Hanchard, Michael George. 1998. Orpheus and Power: The Movimento Negro of Rio de Janeiro and São Paulo, Brazil, 1945-1988. Princeton: Princeton University Press.

H.J. 2013. “The Streets Erupt.” The Economist, June 18. http://www.economist.com/blogs/ americasview/2013/06/protests-brazil?spc=scode\&spv=xm\&ah=9d7f7ab945510a $56 \mathrm{fa} 6 \mathrm{~d} 37 \mathrm{c} 30 \mathrm{~b} 6 \mathrm{f} 1709$.

IBGE. 2011. (Instituto Brazileiro de Geografia e Estatística). Censo demografico 2010 (Rio de Janeiro: IBGE).

Koba, Mark. 2014. "World Cup by the Numbers: Most Expensive Ever!” CNBC, June 12. http://www.cnbc.com/id/101750395. 
Koehne, André. 2007. "Localização do Centro Histórico no mapa de Salvador." Wikimedia Commons, June 27. https://commons.wikimedia.org/wiki/File:Salvador_1_detal he_Porto_Centro_Hist\%C3\%B3rico.png

Kun, Josh. 2005. Audiotopia: Music, Race, and América. Los Angeles: University of California Press.

Lesser, Jeffery. 2013. "Not Raising Bus Fares in Brazil Is a Good Start.” The New York Times, June 16. http://www.nytimes.com/roomfordebate/2013/06/19/will-the-protests-inbrazil-lead-to-change/not-raising-bus-fares-in-brazil-is-a-good-start.

Mahon, Maureen. 2004. Right to Rock: The Black Rock Coalition and the Cultural Politics of Race. Durham: Duke University Press.

McCann, Bryan. 2004. "Samba and National Identity." In Hello, Hello Brazil: Popular Music in the Making of Modern Brazil, 41-95. Durham: Duke University Press.

Mendes, Priscilla, Fabiano Costa, and Nathalia Passarinho. 2013. "Dilma Propõe 5 Pactos e Plebiscito Para Constituinte Da Reforma." O Globo, June 24. http:// g1.globo.com/politica/noticia/2013/06/dilma-propoe-5-pactos-e-plebiscitopara-constituinte-da-reforma-politica.html.

Moehn, Frederick. 2011. “'We Live Daily in Two Countries': Audiotopias of Postdictatorship Brazil." In Brazilian Popular Music and Citizenship, edited by Idelber Avelar and Christopher Dunn, 109-130. Durham: Duke University Press.

Moreira de Carvalho, Inaiá Maria, and Gilberto Corso Pereira. "Segregação socioespacial e desigualdades em Salvador” 2015. Cadernos do CEAS 235:5-22

Neely, Bill. 2014. "Analysis: Brazil Scrambles to Get Ready as World Cup Looms." NBC News, June 11. http://www.nbcnews.com/storyline/world-cup/analysis-brazil-scramblesget-ready-world-cup-looms-n127571.

O Globo. 2013. "Tarifa de Ônibus Em Goiânia Volta a R\$2,70 Na Quinta-feira, Diz CMTC." O Globo. http://g1.globo.com/goias/noticia/2013/06/tarifa-de-onibus-em-goianiavolta-r-270-na-quinta-feira-diz-cmtc.html.

RomaFiat RJ. "Vem Pra Rua - Fiat”. YouTube video, 1:00. Posted [May 2013] https://youtu. be/3AFMybxWiF0.

Scheller, Fernando. 2013. "Vem Pra Rua’ Agora é Dos Brasileiros, Diz Fiat - Economia." Estadão, June 18. http://economia.estadao.com.br/noticias/geral,vem-pra-rua-agorae-dos-brasileiros-diz-fiat,156875e.

Secretaria de Assuntos Estratégicos. 2013. "IPEA revela que 3,5 milhões saíram da pobreza em 2012 (Portal Brasil, em 01.10.2013)”. Government. SAE na Mídia, October 1. http:// www.sae.gov.br/site/?p=18326.

Turino, Thomas. 1993. Moving Away from Silence: Music of the Peruvian Altiplano and the Experience of Urban Migration. Chicago: University of Chicago Press.

Último Segundo. 2013. "Governo Confirma MP Para Diminuir Impostos Do Transporte Público - Brasil - iG." Último Segundo, May 23. http://ultimosegundo.ig.com.br/bra sil/2013-05-23/governo-confirma-mp-para-diminuir-impostos-do-transporte-publi co.html. 
Viana, Rafael, João Paulo Apolinário, and Tiago Gama. 2015. "Um ponto por pessoa: Mapa interativo racial do Brasil.” Patadata. http://patadata.org/maparacial/

Williamson, Theresa. 2013. "Protests Are Just the Beginning; Change Will Come to Brazil (NYT Brazil Protests Debate In-depth Response)." RioOnWatch, June 19. http://www.rioonwatch.org/?p=9630.

Yúdice, George. 2003. The Expediency of Culture: Uses of Culture in the Global Era. Durham: Duke University Press.

Zero Hora. 2013. "Vandalismo marcou protesto em Porto Alegre contra a tarifa de ônibus Zero Hora." Zero Hora, June 14. http://zh.clicrbs.com.br/rs/noticia/2013/06/vandal ismo-marcou-protesto-em-porto-alegre-contra-a-tarifa-de-onibus-4169886.html.

Zweig, Stefan. 1941. Brasil, um país do futuro. Reprint, L\&PM Editores: Porto Alegre, 2006. 